\title{
Antioxidant Property of Cotton Fabric Dyed with Natural Dye Extracted from Bark Peel of Araucaria columnaris
}

\author{
Krishma M. Jadav ${ }^{1 *}$, K.N. Ninge Gowda ${ }^{2}$ \\ ${ }^{1}$ Department of Apparel Technology \& Management, Bangalore University, Bangalore 560001, India) \\ ${ }^{21}$ Department of Apparel Technology \& Management, Bangalore University, Bangalore 560001, India)
}

\begin{abstract}
This research was concerned with dye extraction from bark peel of Araucaria columnaris and with the application of this dye for cotton fabric. Dyeing without any mordant was compared with those obtained with pre-mordanting, simultaneous-mordanting and post-mordanting with alum and myrobalan. The cotton fabrics dyed with and without mordant were evaluated for their color strength $(K / S)$ values. Furthermore, the colorfastness to washing, light, rubbing and perspiration was investigated, the results of which showed fair to good fastness. The antioxidant property of the dyed samples was determined by DPPH method. The results of DPPH assay were positive for all the samples, confirming that natural dyes extracted from Araucaria columnaris bark peel have potential applications for fabric dyeing and producing cotton fabric with efficient antioxidant property.
\end{abstract}

Keywords: Antioxidant, Araucaria columnaris, Color strength, Natural dye, DPPH.

\section{Introduction}

Various parts of plants and animals are used to obtain various shades of natural dyes. The environmental consequences are the reason for the importance of natural dyes around the globe [1]. Natural dyes exhibit better biodegradability and generally have a higher compatibility with environment. The majority of natural dyes need a mordant in the form of metallic salt to create an affinity between the fibre and the pigment. The fastness of a mordant dye depends on the mordant and mordanting method. Myrobalan is a natural mordant and Alum is considered as one of the best metallic mordants in dyeing with natural dyes as its toxicity is low as compared to the other metallic mordants [2,3]. Value addition in clothing has changed the global textile scenario. Research has quite convincingly shown that apparel consumers all over the world are demanding functionality in the products that they use [4]. The wellness or health promoting aspects of textile finishes have become a delightful functional matter in the 21 st century. The extracts of natural products and selected essential oils are added to textiles, which not only have healing properties but also keep the wearer fresh and vigorous [5]. The market for cosmeto-textiles and medical textiles has greatly expanded in recent years. As textile materials have found applications in the cosmetic field, more and more commercial cosmetic textile agents are now available in the market [6].

Antioxidants are natural substances used to regulate the processes triggered by external aggressions, thereby preventing the oxidative stress [7]. In the present work, an attempt has been made to study the colorfastness and antioxidant properties of cotton fabric, dyed with aqueous extract of natural dye obtained from the bark peel of Araucaria columnaris, belonging to the family Araucariaceae [8].

\section{Materials And Methods}

1.1 Collection of plant material:

Plain weave cotton fabric, having specifications $140 \mathrm{~g} / \mathrm{m}^{2}, 124$ ends/inch and 61 picks/inch was used for the study. The bark peel of Araucaria columnaris was collected from Lalbagh Botanical Garden, Bangalore

1.2 Extraction of dye

The collected bark peel was dried under room temperature and ground to a fine powder. The extraction was carried out under alkaline condition with MLR 1:40 at $\mathrm{pH} 10$ for 90 minutes at a temperature of $100^{\circ} \mathrm{C}$. The hot solution was then filtered through a Whatmann No.1 filter paper to obtain a clear filtrate. The filtrate was evaporated to produce crude which was further dried for $24 \mathrm{hrs}$ and ground manually using mortar and pestle to form powder.

\subsection{Selection of Mordant:}

Considering the eco-friendliness and cost effectiveness, the natural mordant Myrobalan [9] and metallic mordant alum [10] were chosen for the dyeing process.

\subsection{Dyeing and Mordanting of cotton fabric:}

The dyeing was carried out at $90^{\circ} \mathrm{C}$ with the dye bath $\mathrm{pH} 5$ containing $5 \%$ of dye in crude, based on weight of fabric (owf) at MLR 1:40 in a temperature controlled open bath dyeing machine for $90 \mathrm{~min}$. The cotton samples were treated with two different mordants, Alum 4\% (owf) and Myrobalan 4\% (owf), separately. 
Three processes of mordanting were used- pre mordanting, simultaneous mordanting and post mordanting. After dyeing, the dyed samples were subsequently washed in $1 \mathrm{gpl}$ non-ionic detergent solution at $60^{\circ} \mathrm{C}$ for 15 min and dried at room temperature.

\subsection{Measurement of surface color strength and color value:}

Color was evaluated by means of $K / S$ and CIELAB values with illuminant D65/10 observer on Gretag Macbeth Color Eye 7000 A Spectrophotometer. Four measurements were made for each sample and the variation in percentage reflectance values over a range of $350-750 \mathrm{~nm}$ was recorded. The $K / S$ values were assessed using the Kubelka-Munk equation [11].

\section{$K / S=(1-R) 2 / 2 R$}

Where, $\mathrm{R}$ is the observed reflectance, $K$ is the absorption co-efficient and $S$ is the light scattering coefficient $[11,12,14]$.

\subsection{Evaluation of colorfastness:}

Color fastness properties of the samples were assessed using ISO standards. Color fastness to washing of dyed fabric was determined as per ISO 105-C06 test method. Color fastness to crocking/rubbing was assessed as per ISO105-X12 test method. Color fastness to light was determined as per AATCC 16.3:2012 method and Color fastness to perspiration was assessed as per ISO 105-E04 1994 method [10,12,13,14].

\subsection{Determination of Antioxidant Activity (DPPH assay):}

Radical scavenging activity of the dyed cotton fabric was determined by measuring the decrease in absorbance of 2,2-Diphenyl-1-picrylhydrazyl radical (DPPH•) at $517 \mathrm{~nm}$ [15]. The DPPH assay is a widely used method to evaluate the ability of antioxidants [16] to scavenge free radicals which are known to be a major factor in biological damages caused by oxidative stress. This assay is known to give reliable information concerning the antioxidant ability of the tested compounds [17,18,19]. This method is based on the ability of DPPH radical to react with hydrogen donor species such as phenolics and flavonoids present in the extract material. Upon receiving a proton from the donor species it loses its color and becomes yellow. As the concentration of phenolic compounds increases, their DPPH radical scavenging activity also increases [20]. The fabric samples were kept immersed in DMSO for a time period of 1 hour at MLR 1:10. The DMSO solution was then filtered and collected from each fabric sample. The solution was evaporated to dryness and the crude collected was weighed and dissolved in DMSO $(10 \mathrm{mg} / \mathrm{ml})$. This was considered as pure sample extract for testing the antioxidant property. $0.3 \mathrm{mM}$ solution of DPPH was prepared in $100 \%$ methanol. To $1 \mathrm{ml}$ of this solution, three different concentrations $100 \mu \mathrm{l}, 300 \mu \mathrm{l}$ and $500 \mu \mathrm{l}$ of sample extract and standard solution (Ascorbic acid) [19] were added separately. The final volume was made up to $4 \mathrm{ml}$ by adding $100 \%$ methanol to each sample mixture and also for standard solution (Ascorbic acid). The same reaction mixture without the extract sample but with equivalent amount of standard phosphate buffer was taken as control. All the sample mixtures and control were shaken thoroughly, and kept in dark at room temperature for 30 mins. The absorbance of the reaction mixtures were measured at $517 \mathrm{~nm}$. The radical scavenging activities were expressed as percentage of inhibition and calculated according to the following equation.

\section{$\%$ DPPH inhibition $=[(\mathrm{AC}-\mathrm{AS}) / \mathrm{AC}] \times \mathbf{1 0 0}$}

Where $\mathrm{AC}=$ absorbance of control and $\mathrm{AS}=$ absorbance of test sample $[21,22]$.

\section{Results And Discussions}

\subsection{Effect of mordants and mordanting method on color strength:}

The color strength values of cotton fabrics dyed with bark peel of Araucaria columnaris obtained in this study by using different mordanting methods are presented in Table 1. From the results, it is clear that the type of mordants has influence on the color strength values. It is evident that the highest values of color strength were achieved with mordants. Table 1 . shows the $K / S$ values and CIELAB co-ordinates $\mathrm{L}, \mathrm{a}^{*}, \mathrm{~b}^{*}, \mathrm{C}$ and $\mathrm{h}$ of cotton fabric dyed with Araucaria columnaris bark peel. It is observed that the $K / S$ values of the dyed material using different mordants (Alum and Myrobalan) increased as compared to the control sample (1.16). The $K / S$ values were highest (5.98) and (5.44) with simultaneous mordanting technique for both Alum and Myrobalan mordanted samples. Similarly the L values of all the dyed samples mordanted with alum and myrobalan decreased indicating deeper shades as compared to control sample. In all mordanting techniques change in a* and $b^{*}$ values were noticed. The values were also positive for all mordanted samples. Color hues (tone) were redder or yellower.

\subsection{Effect of mordants and mordanting method on Color fastness properties:}

The evaluation of color fastness to washing, rubbing, light and perspiration using Alum: pre, simultaneous and post mordanting method and Myrobalan: pre, simultaneous and post mordanting method are presented in Table 2. All the samples including control sample which were subjected to washing fastness showed good color fastness to color change and good to fairly good colorfastness to color staining. The dry rubbing fastness grades were between 4 and 3-4 and wet rubbing fastness grades were between 3-4 and 3 for all the samples including control sample. The light fastness of all the mordanted (alum and Myrobalan) samples 
was better (3 to 3-4) than that of control sample graded-2. Similar trends were observed in case of perspiration fastness. The grades for color change in acidic media for all pre, post and simultaneous mordanted alum and myrobalan samples were good-4, compared to control graded 3-4 and the color fastness to color staining for all the samples including control sample were in between 4 to 3-4. The perspiration fastness for color change in alkaline media was good i.e., 4 for control and all mordanted samples and the color fastness to color staining for all the samples including control sample were good to fairly good (4 to 3-4).

\subsection{Effect of mordants and mordanting method on Antioxidant property:}

The DPPH radical scavenging activity of Ascorbic acid, control and pre, post and simultameous alum mordanted and myrobalan mordanted samples are shown in Fig 1. to Fig 7. This activity was increased by increasing the concentration of the sample extract $(100 \mu \mathrm{L}, 300 \mu \mathrm{L}$ and $500 \mu \mathrm{L})$. DPPH antioxidant assay is based on the ability of 2,2-Diphenyl-1-picrylhydrazyl radical (DPPH), a stable free radical, to decolorize in the presence of antioxidants. The DPPH radical contains an odd electron, which is responsible for the absorbance at $517 \mathrm{~nm}$ and also for a visible deep purple color. When DPPH accepts an electron donated by an antioxidant compound, the DPPH is decolorized, which can be quantitatively measured from the changes in absorbance. Ascorbic acid was used as Standard. All the samples dyed with Araucaria columnaris bark peel extract, including control (dyed without mordant) showed excellent increased \% inhibition with the increase in concentration of extract proving it to be a potential Antioxidant. Among all, the alum simultaneous-mordanted and dyed sample showed the highest $\%$ inhibition $(87.03 \%)$ followed by myrobalan simultaneous-mordanted and dyed sample with \% inhibition (86.90\%).

\section{Tables And Figures}

Table 1. K/S and color co-ordinates of Cotton samples dyed with Araucaria columnaris bark peel

\begin{tabular}{|l|l|l|l|l|l|l|l|}
\hline Sample & Mordanting Method & $K / S$ & $\mathrm{~L}^{*}$ & $\mathrm{a}^{*}$ & $\mathrm{~b}$ & $\mathrm{C}$ & $\mathrm{H}$ \\
\hline Control & Nil & 1.16 & 66.7 & 11.142 & 10.283 & 15.162 & 42.704 \\
\hline \multirow{3}{*}{$\begin{array}{l}\text { Mlum } \\
\text { Mordanted }\end{array}$} & Pre- mord & 4.00 & 52.688 & 12.601 & 20.624 & 24.169 & 58.575 \\
\cline { 2 - 8 } & Sim- mord & 5.98 & 45.125 & 14.096 & 20.657 & 25.008 & 55.69 \\
\cline { 2 - 8 } & Post-mord & 2.54 & 56.736 & 9.666 & 15.893 & 18.602 & 58.693 \\
\hline \multirow{3}{*}{$\begin{array}{l}\text { Myrobalan } \\
\text { Mordanted }\end{array}$} & Pre- mord & 3.48 & 57.251 & 11.459 & 20.591 & 23.565 & 60.905 \\
\cline { 2 - 8 } & Sim- mord & 5.44 & 52.625 & 12.434 & 22.863 & 26.025 & 61.46 \\
\cline { 2 - 8 } & Post-mord & 3.81 & 62.041 & 7.907 & 23.169 & 24.481 & 71.156 \\
\hline
\end{tabular}

Table 2. Fastness grades of Cotton samples dyed with Araucaria columnaris bark peel

\begin{tabular}{|c|c|c|c|c|c|c|c|c|c|c|}
\hline \multirow{3}{*}{ Sample } & \multirow{3}{*}{$\begin{array}{l}\text { Mordanting } \\
\text { method }\end{array}$} & \multirow{2}{*}{\multicolumn{2}{|c|}{$\begin{array}{l}\text { Washing } \\
\text { fastness grades }\end{array}$}} & \multirow{2}{*}{\multicolumn{2}{|c|}{$\begin{array}{l}\text { Rubbing fastness } \\
\text { grades }\end{array}$}} & \multirow{3}{*}{$\begin{array}{l}\begin{array}{l}\text { Light } \\
\text { fastness } \\
\text { grades }\end{array} \\
\text { CC }\end{array}$} & \multicolumn{4}{|c|}{ Perspiration fastness grades } \\
\hline & & & & & & & \multicolumn{2}{|c|}{ Acidic } & \multicolumn{2}{|c|}{ Alkaline } \\
\hline & & $\mathrm{CC}$ & $\mathrm{CS}$ & Dry & Wet & & $\mathrm{CC}$ & $\mathrm{CS}$ & $\mathrm{CC}$ & $\mathrm{CS}$ \\
\hline Control & Nil & 4 & $3-4$ & 4 & $3-4$ & 2 & $3-4$ & $3-4$ & 4 & $3-4$ \\
\hline \multirow{3}{*}{$\begin{array}{l}\text { Alum } \\
\text { Mordanted }\end{array}$} & Pre-mord & 4 & $3-4$ & 4 & $3-4$ & 3 & 4 & $3-4$ & 4 & $3-4$ \\
\hline & Sim-mord & 4 & $3-4$ & $3-4$ & 3 & 3 & 4 & $3-4$ & 4 & $3-4$ \\
\hline & Post-mord & 4 & 4 & 4 & $3-4$ & 3 & 4 & $3-4$ & 4 & $3-4$ \\
\hline \multirow{3}{*}{$\begin{array}{l}\text { Myrobalan } \\
\text { Mordanted }\end{array}$} & Pre-mord & 4 & $3-4$ & 4 & $3-4$ & $3-4$ & 4 & $3-4$ & 4 & $3-4$ \\
\hline & Sim-mord & 4 & $3-4$ & $3-4$ & 3 & 4 & 4 & $3-4$ & 4 & $3-4$ \\
\hline & Post-mord & 4 & 4 & 4 & $3-4$ & 4 & 4 & 4 & 4 & 4 \\
\hline
\end{tabular}

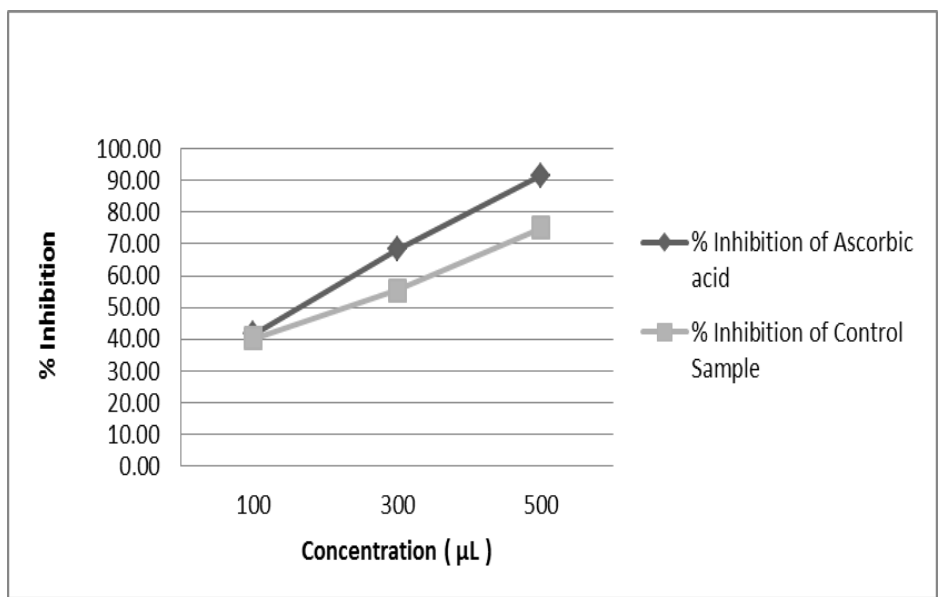

Fig. 1 DPPH assay of Control sample dyed with Araucaria columnaris bark peel extract 


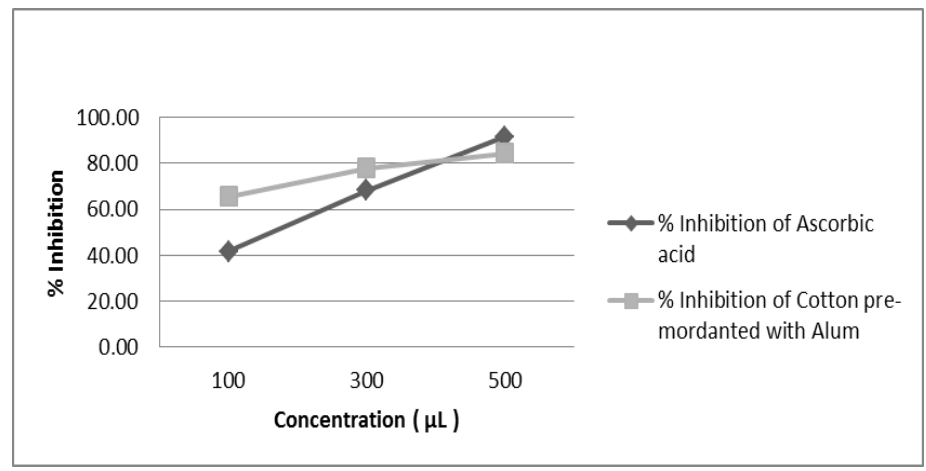

Fig. 2 DPPH assay of Alum pre-mordanted sample dyed with Araucaria columnaris

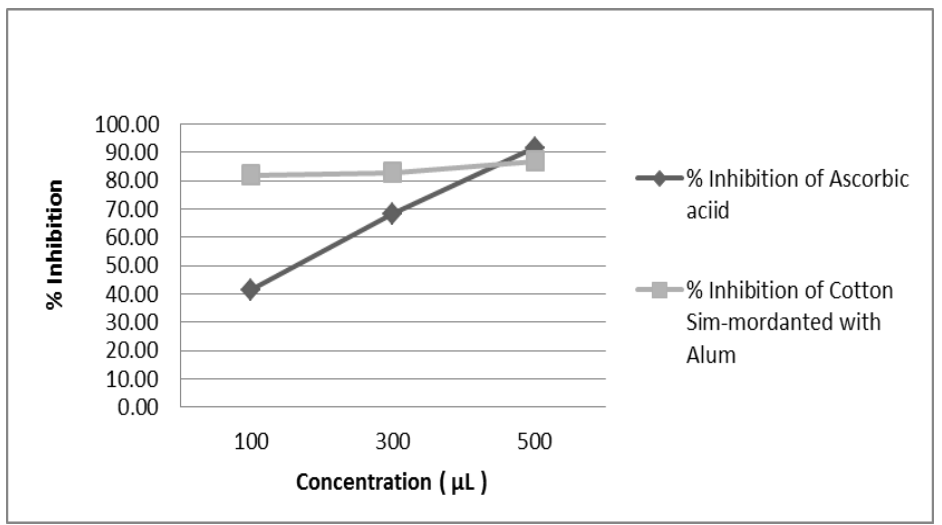

Fig. 3 DPPH assay of Alum simultaneous-mordanted sample dyed with Araucaria columnaris

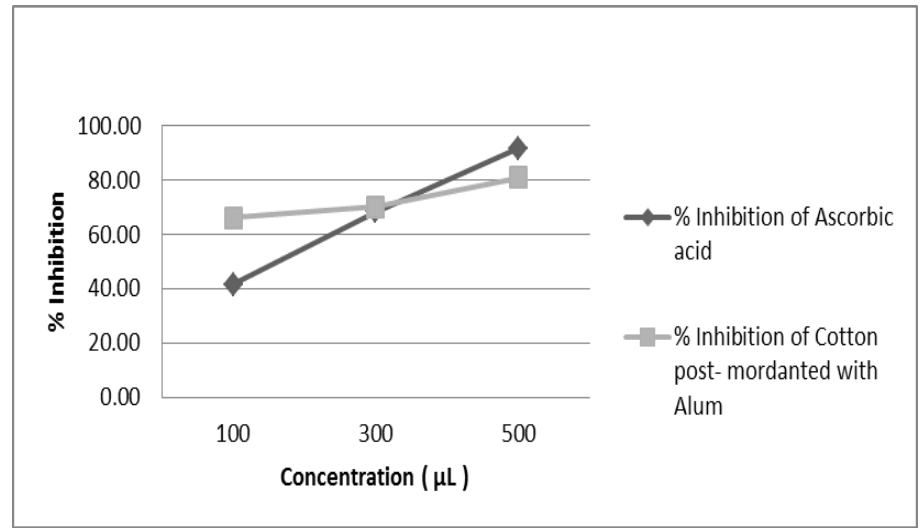

Fig. 4 DPPH assay of Alum post-mordanted sample dyed with Araucaria columnaris

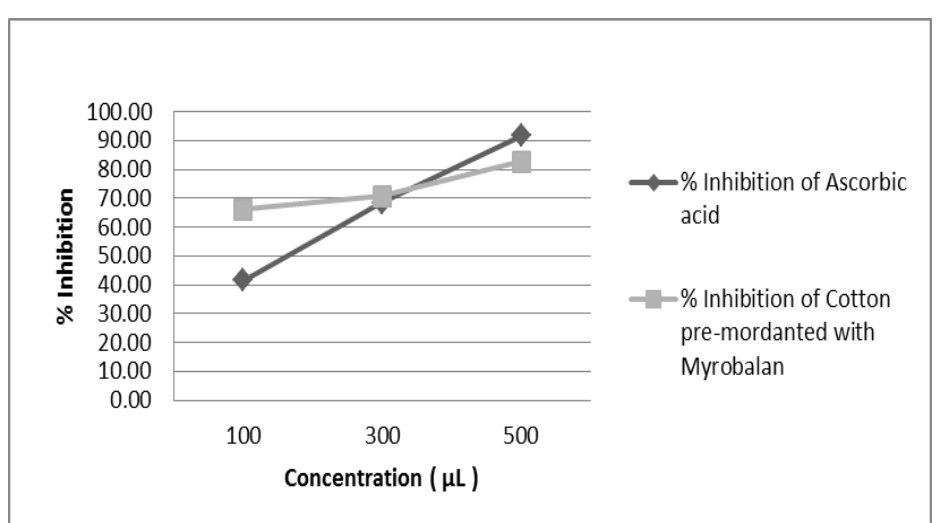

Fig. 5 DPPH assay of Myrobalan pre-mordanted sample dyed with Araucaria columnaris 


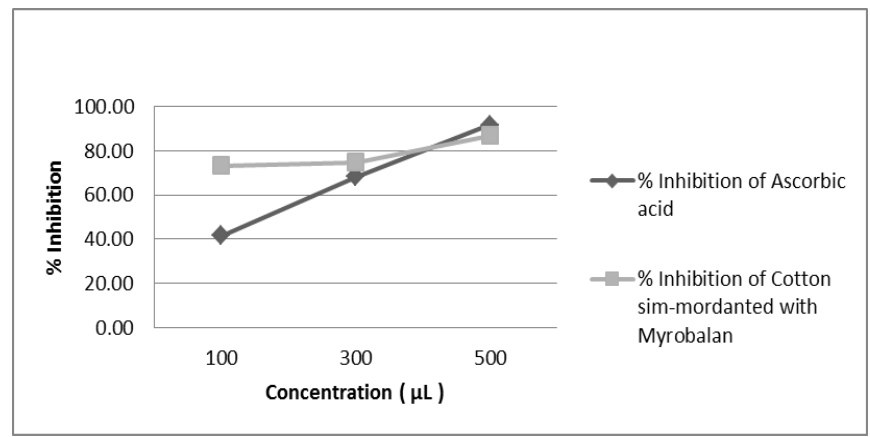

Fig. 6 DPPH assay of Myrobalan simultaneous-mordanted sample dyed with Araucaria columnaris

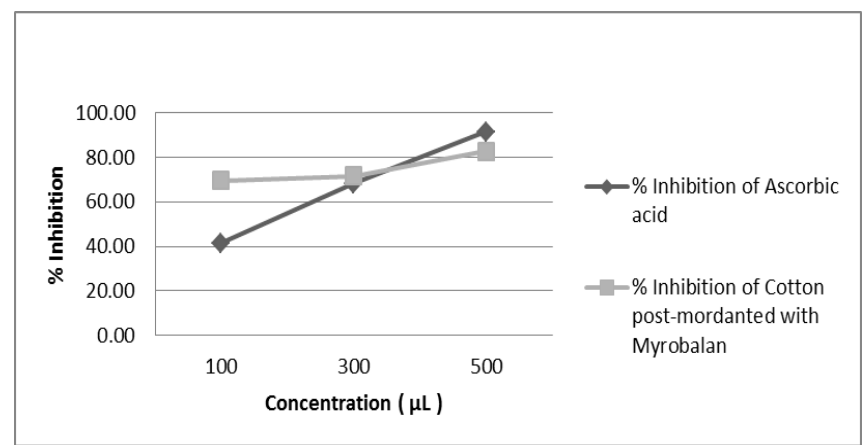

Fig. 7 DPPH assay of Myrobalan post-mordanted sample dyed with Araucaria columnaris

\section{Conclusion}

The natural colorant obtained from Araucaria columnaris bark peel has been successfully used as an eco-friendly dye to obtain different shades of Brown. Mordant treatment not only improved the color strength of this natural dye but also resulted in numerous shades. All the mordanted samples showed excellent color strength values, fair to good color fastness values and strong antioxidant activity by inhibiting DPPH. The increase in \% inhibition of all the samples corresponded with the color strength values. The samples with highest $K / S$ values showed the highest \% inhibition. Also, the \% inhibition was increased by the increase in concentration of the sample extract, proving it to be an efficient antioxidant.

\section{References}

[1]. S. Naz, A. I. Bhatti, and S. Adeel, Dyeing properties of cotton fabric using un-irradiated and gamma irradiated extracts of Eucalyptus camaldulensis bark powder, Indian Journal of Fibre \& Textile Research, 36, 2011, 132-136

[2]. H. T. Deo, and R. Paul, Dyeing of ecru denim with onion extract as a natural dye using potassium alum in combination with harda and tartaric acid, Indian Journal of Fibre \& Textile Research, 25, 2000, 217-220

[3]. D. Cristea, and G. Vilarem, Improving light fastness of natural dyes on cotton yarn, Dyes and Pigments, 71, 2006, 39-46

[4]. M. P. Sathianarayanan, B. M. Chaudhari, and N. V. Bhat, Development of durable antibacterial agent from ban-ajwain seed (Thymus serpyllum) for cotton fabric, Indian Journal of Fibre \& Textile Research, 36, 2011, 234-241

[5]. M. K. Singh, V. K. Varun, and B. K. Behera, Cosmetotextiles: State of Art, Fibres \& Textiles in Eastern Europe, 19, 2011, 27-33

[6]. S. Y. Cheng, C. W. M. Yuen, C. W. Kan, and S. Y. Li, A Comprehensive Study of Silicone-based Cosmetic Textile Agent, Fibers and Polymers, 10(1), 2009, 132-140

[7]. C. Alonso, M. Martí, V. Martínez, L. Rubio, J. L. Parra, and L. Coderch, Antioxidant cosmeto-textiles: skin assessment, European Journal of Pharmaceutics and Biopharmaceutics, 84(1), 2013, 192-199

[8]. S. K. Devi, J. Rathinamala, and S. Jayashree, Phytochemical and Therapautic effect of Araucaria columnaris resin extracts on clinical pathogens European journal of molecular biology and biochemistry 1(5), 2014 182-185

[9]. M. A. Khan, M. Khan, P. K. Srivastava, and F. Mohammad, Extraction of natural dyes from myrobalan, gallnut and pomegranate, and their application on wool, Colourage, 52, 2005, 53-60

[10]. S. Ali, T. Hussain, and R. Nawaz, Optimization of alkaline extraction of natural dye from Henna leaves and its dyeing on cotton by exhaust method, Journal of Cleaner Production, 17, 2009, 61-66

[11]. V. N. Swamy, K. N. N. Gowda, and R. Sudhakar, Natural Dye From the Bark of Casuarina Equisetifolia for Silk, International Journal of Pharma and Bio Sciences, 4(3): (B), 2013, 94-104

[12]. M. Shahid, A. Ahmad, M. Yusuf, M. I. Khan, S. A. Khan, N. Manzoor, and F. Mohammad, Dyeing, fastness and antimicrobial properties of woolen yarns dyed with gallnut (Quercus infectoria Oliv.) extract, Dyes and Pigments, 95, 2012, 53-61

[13]. R. Purwar, P. Sahoo, M. Jain, U. Bothra, P. Yadav, J. Juneja, and C. M. Srivastava, Dope dyeing of polyacrylonitrile filaments with Ratanjot, Indian Journal of Fibre \& Textile Research, 41, 2016, 84-88

[14]. V. N. Swamy, K. N. N. Gowda, and R. Sudhakar, Dyeing of Silk using Madhuca longifolia as natural dye source, Indian Journal of Fibre \& Textile Research, 40, 2015, 419-424

[15]. S. S. Khadabadi, S. L. Deore, and B. A. Baviskar, Quantitative Chemical Estimation, Experimental Phytopharmacognosy, 2nd ed., (Nirali Prakashan Pub, India, 2013), pp. 4.27

[16]. G. Sahgal, S. Ramanathan, S. Sasidharan, M. N. Mordi, S. Ismail, and S. M. Mansor, In Vitro Antioxidant and Xanthine Oxidase Inhibitory Activities of Methanolic Swietenia mahagoni Seed Extracts Molecules, 14, 2009, 4476-4485 
[17]. C. Grace-Lynn, I. Darah, Y. Chen, L. Y. Latha, S. L. Jothy, and S. Sasidharan, In Vitro Antioxidant Activity Potential of Lantadene A, a Pentacyclic Triterpenoid of Lantana Plants, Molecules, 17, 2012, 11185-11198

[18]. D. Huang, B. Ou, and R. L. Prior, The chemistry behind antioxidant capacity assays, Journal of Agriculture and Food Chemistry, 53, 2005, 1841-1856

[19]. S. Parthasarathy, J. B. Azizi, S. Ramanathan, S. Ismail, S. Sasidharan, M. I. M. Said, and S. M. Mansor, Evaluation of Antioxidant and Antibacterial Activities of Aqueous, Methanolic and Alkaloid Extracts from Mitragyna Speciosa (Rubiaceae Family) Leaves Molecules, 14, 2009, 3964-3974

[20]. C. D. Porto, S. Calligaris, E. Cellotti, and M. C. Nicoli, Antiradical properties of commercial cognacs assessed by the DPPH• test, Journal of Agriculture and Food Chemistry, 48, 2000, 4241-4245

[21]. K. S. Rao, P. R. Munjuluri, and N. K. Keshar, Invitro Antioxidant Activity and Total Phenolic Content of Mimusops elengi Bark Indian Journal of Pharmaceutical and Educational Research, 45, 2011, 317-323

[22]. F. Aqil, I. Ahmad, and Z. Mehmood, Antioxidant and Free Radical Scavenging Properties of Twelve Traditionally Used Indian Medicinal Plants Turkish Journal of Biology, 30, 2006, 177-183 